\title{
Time of emergence of trends in ocean biogeochemistry
}

\author{
K. M. Keller ${ }^{1,2}$, F. Joos ${ }^{1,2}$, and C. C. Raible ${ }^{1,2}$ \\ ${ }^{1}$ Climate and Environmental Physics, Physics Institute, University of Bern, Sidlerstrasse 5, 3012 Bern, Switzerland \\ ${ }^{2}$ Oeschger Centre for Climate Change Research, University of Bern, Zähringerstrasse 25, 3012 Bern, Switzerland
}

Correspondence to: K. M. Keller (keller@ climate.unibe.ch)

Received: 23 October 2013 - Published in Biogeosciences Discuss.: 20 November 2013

Revised: 26 May 2014 - Accepted: 2 June 2014 - Published: 9 July 2014

\begin{abstract}
For the detection of climate change, not only the magnitude of a trend signal is of significance. An essential issue is the time period required by the trend to be detectable in the first place. An illustrative measure for this is time of emergence (ToE), that is, the point in time when a signal finally emerges from the background noise of natural variability. We investigate the ToE of trend signals in different biogeochemical and physical surface variables utilizing a multimodel ensemble comprising simulations of 17 Earth system models (ESMs). We find that signals in ocean biogeochemical variables emerge on much shorter timescales than the physical variable sea surface temperature (SST). The ToE patterns of $p \mathrm{CO}_{2}$ and $\mathrm{pH}$ are spatially very similar to DIC (dissolved inorganic carbon), yet the trends emerge much faster - after roughly $12 \mathrm{yr}$ for the majority of the global ocean area, compared to between 10 and $30 \mathrm{yr}$ for DIC. ToE of 45-90 yr are even larger for SST. In general, the background noise is of higher importance in determining ToE than the strength of the trend signal. In areas with high natural variability, even strong trends both in the physical climate and carbon cycle system are masked by variability over decadal timescales. In contrast to the trend, natural variability is affected by the seasonal cycle. This has important implications for observations, since it implies that intra-annual variability could question the representativeness of irregularly sampled seasonal measurements for the entire year and, thus, the interpretation of observed trends.
\end{abstract}

\section{Introduction}

Since the beginning of the industrialization, the climate system has undergone substantial changes. Responsible for these changes is the $\mathrm{CO}_{2}$ emitted by mankind through com- bustion of fossil fuels, land-use change and industrial processes (e.g., Hegerl et al., 2007), which have brought the global carbon cycle out of steady state. The carbon cycle and the physical climate system strongly interact with each other (Joos et al., 1999), as illustrated by the manifold impacts of climate change on the global oceans. In addition to sea-level rise and ocean warming (e.g., Hegerl et al., 2007; Levermann et al., 2013; Dutkiewicz et al., 2013), we observe and model carbon-cycle related ocean acidification (Steinacher et al., 2009) and deoxygenation (Frölicher et al., 2009; Keeling et al., 2010). Consequently, a sound knowledge of the joint processes is a necessity not only for the correct detection of past and present trends, but also for robust projections of the future. Still, it remains a challenge to identify clear external forcing signals. An important issue is the presence of internal variability, which has the potential to enhance or mask forced trends in the atmosphere, land, or ocean (e.g., Latif et al., 1997; Raible et al., 2005; Frölicher et al., 2009; Dolman et al., 2010; Keller et al., 2012). For instance, McKinley et al. (2011) stated that carbon dioxide trends in the North Atlantic require $25 \mathrm{yr}$ to exceed the range of decadal-scale variability. The correct assessment of trends is complicated in the ocean. Especially for the carbon cycle, observational data are scarce and limited in both time and space. Accordingly, models are often the only possibility to investigate trends and variability on respective temporal and spatial scales.

The detection of forced trends in the climate or carbon cycle system is a signal-to-noise problem (see, e.g., Santer et al., 2011, and references therein). For a successful detection, the signal has to be of a magnitude that durably exceeds the envelope of background variability. One possible way to quantify this is the estimation of the time of emergence (ToE) of a signal, that is, the point in time at which 
the ratio between signal (=trend) and noise (= background variability) exceeds a certain threshold.

The ToE method has been applied to a number of physical variables such as surface air temperature (Karoly and Wu, 2005; Diffenbaugh and Scherer, 2011; Mahlstein et al., 2011, 2012; Hawkins and Sutton, 2012; Mora et al., 2013) and precipitation (Giorgi and $\mathrm{Bi}, 2009$ ), the combination of these two variables being indicative of future climate change hotspots (Diffenbaugh and Giorgi, 2012), or the imminent shift of climate regions (Mahlstein et al., 2013). A common approach to estimate ToE is the comparison of modeled noise (usually the standard deviation of an unforced control simulation) and observed (Karoly and $\mathrm{Wu}, 2005$ ) or modeled (Mahlstein et al., 2011; Hawkins and Sutton, 2012) trends. Other approaches derive both signal and noise from the same observational time series (Mahlstein et al., 2011, 2012) or forced model simulation (Giorgi and Bi, 2009; Diffenbaugh and Scherer, 2011; Diffenbaugh and Giorgi, 2012; Mora et al., 2013).

In ocean biogeochemistry, the ToE method is not prevalent. Ilyina et al. (2009) and Ilyina and Zeebe (2012) applied a global biogeochemistry ocean model in combination with an observation-derived detection threshold to investigate the effect of imminent ocean acidification on carbonate dissolution. Compared to present-day, they detected trends in surface total alkalinity (TA) by 2040 and 2070, respectively. Friedrich et al. (2012) used three Earth system models (ESMs) to detect anthropogenic trends in ocean acidification, thereby the noise is defined as the amplitude of the pre-industrial annual cycle. They concluded that, by 2010 , anthropogenic trends in the saturation state of aragonite $\left(\Omega_{\mathrm{A}}\right)$ are already detectable in many parts of the global surface ocean. An exception is the eastern equatorial Pacific, which is strongly influenced by high ENSO-related natural variability. In line with these results, and based on a CMIP5 model ensemble, Mora et al. (2013) projected that global mean $\mathrm{pH}$ exceeds the noise of historical variability by 2008 ( $\pm 3 \mathrm{yr}$ ). Hereby, they defined the noise as the amplitude of the minimum and maximum values of the historical simulation (1860-2005). Based on an eddy-resolving regional ocean model, Hauri et al. (2013) investigated $\mathrm{pH}$ and $\Omega_{\mathrm{A}}$ in the California Current System. For present-day, they found that trends in both variables are already detectable with respect to preindustrial variability levels.

Here, we utilize a model ensemble of 17 ESMs to investigate the ToE of trends in surface ocean biogeochemistry. For maximum comparability with the available observations, we focus on three frequently measured carbon cycle variables, dissolved inorganic carbon (DIC), $p \mathrm{CO}_{2}$ and $\mathrm{pH}$, and seasurface temperature (SST). In the next section, models and ToE methods are introduced. In the result section, we first present the multi-model mean of the ideal case with respect to observations, i.e., complete seasonal data coverage. Secondly, the impact of seasonality is addressed based on two models. Finally, conclusions are given.

\section{Methods}

This study is based on an "ensemble of opportunity" comprising 17 Earth system models: NCAR CESM1 (Moore et al., 2013), 5 models from the OCMIP5 framework: NCAR CCSM3-BEC (Collins et al., 2006), NCAR CSM1.4-carbon (Doney et al., 2006), BCCR BCM-C (Assmann et al., 2010), IPSL-CM4 (Aumont et al., 2003) and COSMOS (Jungclaus et al., 2006); and 11 CMIP5 models: (Taylor et al., 2011), CanESM2 (Christian et al., 2010), GFDL-ESM2M (Dunne et al., 2012), HadGEM2-CC and HadGEM2-ES (Palmer and Totterdell, 2001), IPSL-CM5A-LR, IPSL-CM5A-MR and IPSL-CM5B-LR (Séférian et al., 2013), MIROC-ESM (Watanabe et al., 2011), MPI-ESM-LR and MPI-ESM-MR (Ilyina et al., 2013), and NorESM1-ME (Tjiputra et al., 2013).

We use historical simulations covering the years 1870 1999 with annual resolution; for comparability, all model output is regridded to a $1^{\circ} \times 1^{\circ}$ grid. ToE is defined as

$\mathrm{ToE}=(2 \times N) / S$,

where $S$ is the trend and $N$ a measure for variability.

For each grid cell, $S$ is defined as the linear trend (per year) over the period 1970-1999. A different approach is the computation of the trend by applying a smoothing spline on the time series; test calculations for 1970-1999 yield comparable results. Figure 1 exemplarily illustrates the two approaches and the good agreement between them based on the model NCAR CESM1. We note that by also applying the linear trend from the 1970 to 1999 period in the future, any changes in trends are not explicitly accounted for. Changes in trends are likely to remain relatively small in the next few decades, but trends will differ considerably between business-as-usual and stringent mitigation scenarios by the end of this century (e.g., Steinacher et al., 2009; Cocco et al., 2013; Bopp et al., 2013). For $N$, the standard deviation (SD) over the entire simulation, 1870-1999, is used. Prior to this last step, the data are detrended via a spline approach (cut-off period: $40 \mathrm{yr}$; Enting, 1987).

For illustration purposes, we calculate ToE for DIC at a location in the subtropical North Pacific (see also Fig. 1). By inserting the respective values for $S\left(0.94 \mathrm{mmol} \mathrm{m}^{-3} \mathrm{yr}^{-1}\right)$ and $N\left(7.24 \mathrm{mmol} \mathrm{m}^{-3}\right)$, we obtain $(2 \times 7.24) / 0.94=15.4 \mathrm{yr}$, that is, a (rounded up) ToE of 16 yrs. The ensemble mean of ToE is computed from the ToE of individual models, and not from the ensemble mean of $S$ and $N$. Note that the presented ensemble mean patterns, i.e., the averages of all 17 models, are not necessarily physically consistent.

$\mathrm{ToE}$ is a measure for the point in time when the trend signal $(S \times$ ToE $)$ exceeds two times the background variability $N$ - i.e., the approximate $95 \%$ confidence interval of the background variability. The choice of the detection threshold differs between studies, other approaches are, for example, one SD of seasonal or annual means (Hawkins and Sutton, 2012), observation-based thresholds (Ilyina et al., 2009; 


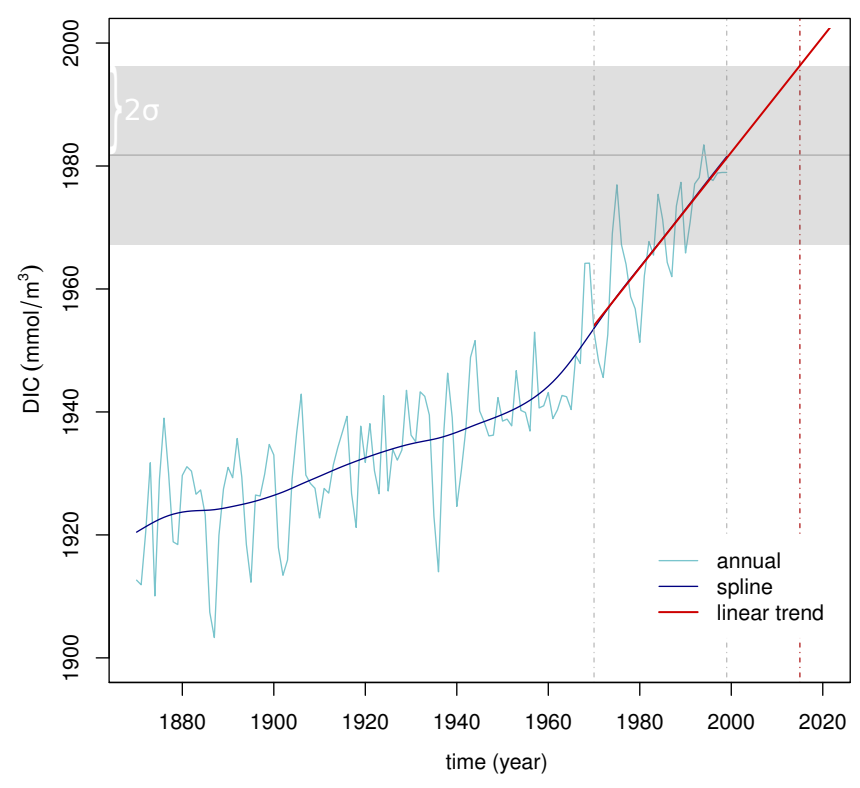

Figure 1. NCAR CESM1: annual time series (light blue), corresponding smoothing spline (dark blue), and linear trend (red) of dissolved inorganic carbon (DIC; $\mathrm{mmol} \mathrm{m}^{-3}$ ) at $22^{\circ} \mathrm{N}, 158^{\circ} \mathrm{W}$, the proximate location of the Hawaii Ocean Time-series (HOT; Keeling et al., 2004). The grey bar represents two times the standard deviation of the detrended time series (i.e., annual-spline). The spline is calculated with a cut-off period of $40 \mathrm{yr}$. The linear trend is based on the years 1970-1999 of annual, as indicated by the grey vertical lines. The intersect between the red vertical line and the upper border of the grey bar $(x=2015)$ shows when the trend leaves the envelope of background variability and, from then on, is detectable. Consequently, the ToE at this location is 16 yr (2015-1999).

Ilyina and Zeebe, 2012) or the range of the pre-industrial annual cycle (Friedrich et al., 2012). Here, we use the rather conservative value of two SDs of interannual variability. For a threshold of one SD, the ToE would be half, accordingly.

By calculating $S$ over a time period of $30 \mathrm{yr}$, to a certain degree we can rule out interference of low-frequency variability in the detection of the trend (see e.g., McKinley et al., 2011). A ToE of only a few decades, as is especially the case for the three carbon cycle variables (see Sect. 3.1), is thus a strong indicator for the significance of the respective trend. This is confirmed by a significance test ( $t$ test, $5 \%$ level) of the trend of the underlying $30 \mathrm{yr}$ time series (not shown): for all 17 models, all trends in $\mathrm{pH}$ are significant. The trends in $p \mathrm{CO}_{2}$ are also significant, yet with localized insignificant exceptions in the Southern Ocean (BCCR BCMC, IPSL-CM5A-MR) and the upwelling region off Peru and Chile (CanESM2). Trends in DIC are significant in large parts of the global oceans, exceptions are the high latitudes and the equatorial Pacific. Statistically significant trends in SST are less widespread and corresponding regional results are highly model-dependent.
In using these definitions, we assume that (i) the trend from 1970 to 1999 is linear, (ii) the SD is constant over time and, by using annual averages, (iii) that trends and SD patterns are comparable for annual, seasonal or monthly data. To verify (i), the global trends of surface DIC and SST for the period 1970-1999 are investigated. For all models, we find that trends in global surface DIC can be represented by a linear function. SST shows larger inter-annual variability, yet likewise with a linear underlying trend. For (ii), we investigate the detrended data (1870-1999) of DIC and SST of all 17 models (not shown). The comparison of SD fields calculated for the first and second $65 \mathrm{yr}$ ( $F$ test, $5 \%$ level) illustrates that differences only occur in very localized instances, consequently we suggest that this assumption is confirmed. Assumption (iii) can be confirmed for the trend patterns. The standard deviations, however, differ considerably in magnitude - we address this issue in Sect. 3.2.

\section{Results and discussion}

In the ocean, observations are scarce and often limited in time, e.g., to specific seasons. We address this by splitting our analysis in two parts. First, the complete model ensemble is used to investigate the "best case" with respect to observations, i.e., complete annual data coverage (Sect. 3.1). In a second step, and based on two individual models, the focus is on the months January and July to estimate the impact of seasonality (Sect. 3.2).

\subsection{ToE - ensemble mean}

Figure 2 shows the ensemble mean ToE patterns of dissolved inorganic carbon (DIC), $p \mathrm{CO}_{2}, \mathrm{pH}$ and sea-surface temperature (SST), all variables on surface level. We find that trend signals in the three carbon cycle variables emerge on much shorter timescales than the physical climate variable SST. The ToE pattern of SST is very noisy, varying typically between 45 and $90 \mathrm{yr}$. The exception are areas around the equator in the Atlantic, Indian and western Pacific Ocean, with values of approximately $35 \mathrm{yr}$. A large coherent area with $\mathrm{ToE}>80 \mathrm{yr}$ can be found in the (eastern) equatorial Pacific. The trend in DIC appears in large parts of the global oceans after approximately 10-30 yr; higher values are found at high latitudes, especially the Arctic Ocean $(\approx 50 \mathrm{yr})$, and localized in the equatorial Pacific (up to $\approx 70 \mathrm{yr}$ ). ToE of $p \mathrm{CO}_{2}$ and $\mathrm{pH}$ show a very similar pattern. However, the trends emerge much faster for $p \mathrm{CO}_{2}$ and $\mathrm{pH}$ than for DIC: after $\approx 12 \mathrm{yr}$ for the majority of the global ocean area, $14-18 \mathrm{yr}$ in the Arctic Ocean and $\approx 20 \mathrm{yr}$ in the equatorial Pacific. A likely reason for these different timescales of DIC and $\mathrm{pH} / p \mathrm{CO}_{2}$ are nonlinear processes in ocean chemistry described by the buffer factor (or Revelle factor; Revelle and Suess, 1957), which result in increases of $p \mathrm{CO}_{2}$ of approximately 10 times the magnitude of the corresponding relative 


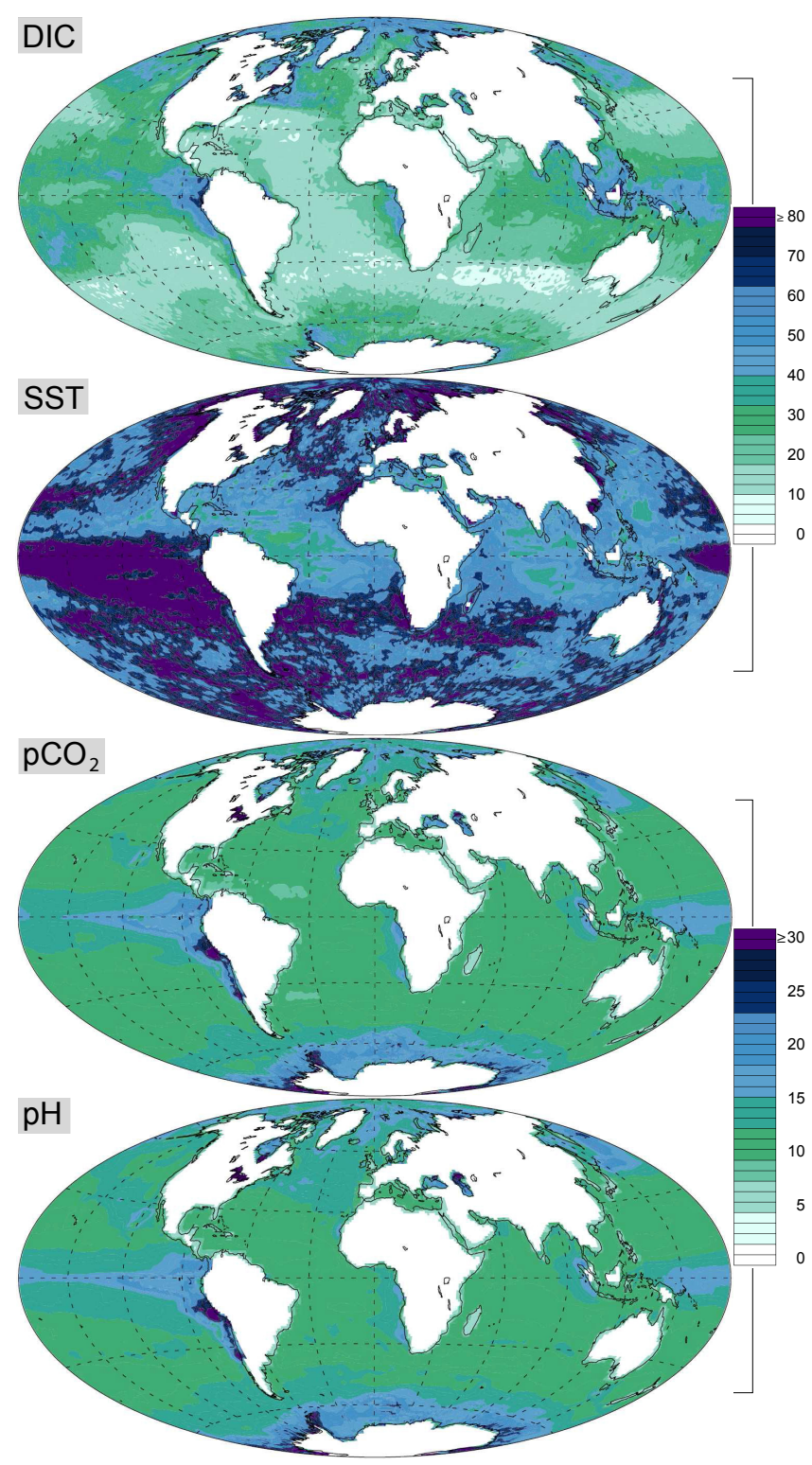

Figure 2. ToE (years) of dissolved inorganic carbon (DIC; mmol m${ }^{-3}$ ), sea-surface temperature (SST; $\left.{ }^{\circ} \mathrm{C}\right), p \mathrm{CO}_{2}$ (ppmv), and total $\mathrm{pH}$. Ensemble mean, all variables on surface level. Note the different scales for DIC/SST and $p \mathrm{CO}_{2} / \mathrm{pH}$.

increases in DIC. In contrast to DIC, relatively high ToE values are found for both $p \mathrm{CO}_{2}$ and $\mathrm{pH}$ in the Southern Ocean and in the upwelling region off Peru and Chile (both regions, localized $>30 \mathrm{yr}$ ). Taking past changes since the beginning of the industrialization into account, the low ToE values, especially for $p \mathrm{CO}_{2}$ and $\mathrm{pH}$, indicate that anthropogenic trends are already detectable in large parts of the global surface oceans. This is in agreement with Mora et al. (2013) for $\mathrm{pH}$ and Friedrich et al. (2012) concerning the saturation state of aragonite $\left(\Omega_{\mathrm{A}}\right)$, another measure for ocean acidification.
A direct evaluation of ToE is difficult, if not impossible, due to the lack of suitable observations. However, it is feasible for the underlying fields signal $S$ and noise $N$ (Fig. 3a and $3 b$ ). These two variables are of added value since they allow determining the importance of $S$ and $N$ for the resulting ToE fields. The top row of Fig. $3 \mathrm{a}$ and $3 \mathrm{~b}$ shows $S$, the trend/decade over the years 1970-1999, the second row illustrates $N$, the standard deviation of the (detrended) years 1870-1999. To evaluate these patterns, we compiled a number of observations (Table 1). These time series remarkably illustrate the importance of natural variability. The Bermuda Time Series Station (BATS), located near Bermuda in the North Atlantic, and Station ALOHA, the site of the US JGOFS Hawaii Ocean Time-series program (HOT) located in the central North Pacific, contribute trends over multiple yet overlapping time periods. It is striking how a different start (BATS) or end (ALOHA) year can change the trend estimation of a time series. At ALOHA, trends of DIC and SST even switch from negative to positive and vice versa, depending on the time period. This issue is addressed in a recent study by Fay and McKinley (2013). These authors investigated trends in surface ocean $p \mathrm{CO}_{2}$ measurements between 1981 and 2010 for periods of $4 \mathrm{yr}$ to up to $30 \mathrm{yr}$. They found that, on shorter timescales, trends of surface $p \mathrm{CO}_{2}$ are sensitive to variability presumably linked to climatic oscillations and, consequently, may vary between different periods. Accordingly, this caveat has to be taken into account when comparing modeled and observed trends over relatively short time periods. Fay and McKinley also find that the influence of climatic oscillations fades when analysis periods are between 25 and $30 \mathrm{yr}$, as used in this study to determine trends. We note that a direct comparison between the trend signals computed by Fay and McKinley and our trend signal is hampered by the fact that Fay and McKinley use relatively sparse observational data to determine trends. Consequently, a comparison of modeled and observed trends has to be undertaken with caution. For DIC, features like a stronger trend at BATS compared to ESTOC are captured by the ensemble mean. Overall, however, the models slightly underestimate the observed trends by up to $5 \mathrm{mmol} \mathrm{m}^{-3} \mathrm{yr}^{-1}$. For $p \mathrm{CO}_{2}$, both model mean and observations show robust positive trends for large parts of the global oceans. Yet, the ensemble locally underestimates the observed trends, for example at station ALOHA (with respect to 1988-2002: 10 ppmv). For $\mathrm{pH}$, the models capture the general trend, i.e., prevalent ocean acidification. Both models and observations illustrate this with comparable negative values. For SST, the model ensemble shows widespread positive trends, the exception is a localized area in the Southern Pacific. The observed trends span a wide range from positive to negative, due to natural variability as discussed above. A comparison of the positive observed values with the ensemble indicates that models and observed time series are in the same range of magnitude. Further, we utilize the SST fields of the reanalysis data set HadISST1 (Rayner et al., 2003). Based 
Table 1. Observed trends/year of dissolved inorganic carbon (DIC; $\mathrm{mmol} \mathrm{m}^{-3}$ ), $p \mathrm{CO}_{2}$ (ppmv or $\mu$ atm), total $\mathrm{pH}$ and sea-surface temperature $\left(\mathrm{SST} ;{ }^{\circ} \mathrm{C}\right)$, all variables on surface level. Note that we include only directly measured DIC, that is, not salinity-normalized.

\begin{tabular}{|c|c|c|c|c|}
\hline Region and years & DIC & $p \mathrm{CO}_{2}$ & $\mathrm{pH}$ & SST \\
\hline \multicolumn{5}{|l|}{ North Atlantic } \\
\hline $1983-2011(\text { BATS })^{\mathrm{a}}$ & $1.53 \pm 0.12$ & $1.62 \pm 0.21$ & $-0.0016 \pm 0.0022$ & $-0.0075 \pm 0.021$ \\
\hline 1988-2011 (BATS) ${ }^{\mathrm{b}}$ & $1.51 \pm 0.08$ & $2.13 \pm 0.16$ & $-0.0022 \pm 0.0002$ & $-0.011 \pm 0.002$ \\
\hline $1995-2004(\text { ESTOC })^{\mathrm{c}}$ & $0.41 \pm 0.12$ & $1.55 \pm 0.43$ & $-0.0017 \pm 0.0004$ & $0.002 \pm 0.019$ \\
\hline $1985-2008$ (Iceland) $^{\mathrm{d}}$ & $1.44 \pm 0.23$ & - & $-0.002 \pm 0.005$ & - \\
\hline \multicolumn{5}{|l|}{ North Pacific } \\
\hline $1973-2005(\text { Line } P)^{\mathrm{e}}$ & - & $1.36 \pm 0.16$ & - & - \\
\hline $1992-2008(\text { KNOT })^{\mathrm{f}}$ & $1.3 \pm 0.3$ & - & - & $0.039 \pm 0.021$ \\
\hline $1994-2008^{\mathrm{g}}$ & - & $1.54 \pm 0.33$ & $-0.020 \pm 0.007$ & - \\
\hline \multicolumn{5}{|l|}{ Pacific (near Hawaii) } \\
\hline $1988-1996(\text { ALOHA })^{\mathrm{h}}$ & $-0.24 \pm 0.46$ & $1.4 \pm 0.2$ & - & $0.02 \pm 0.02$ \\
\hline 1988-2002 (ALOHA $)^{\mathrm{h}}$ & $2.64 \pm 0.25$ & $2.5 \pm 0.1$ & - & $-0.02 \pm 0.01$ \\
\hline 1988-2007 (ALOHA) ${ }^{\mathrm{i}}$ & - & $1.88 \pm 0.16$ & $-0.0019 \pm 0.0002$ & $0.026 \pm 0.016$ \\
\hline \multicolumn{5}{|l|}{ Equatorial Pacific } \\
\hline 1974-2004 (Niño 3.4) & - & $1.13 \pm 0.31$ & - & $-0.01 \pm 0.02$ \\
\hline 1974-2004 (WPWP) ${ }^{j}$ & - & $1.91 \pm 0.22$ & - & $0.05 \pm 0.01$ \\
\hline \multicolumn{5}{|l|}{ Southern Ocean } \\
\hline 1991-2007 (Indian Ocean) ${ }^{\mathrm{k}}$ & - & $2.11 \pm 0.07$ & - & $-0.11 \pm 0.03$ \\
\hline 1995-2008 (Indian/Pacific) ${ }^{1}$ & $1.0 \pm 0.6$ & $2.2 \pm 0.2$ & - & $0.01 \pm 0.06$ \\
\hline $1998-2010{\text { (Pacific })^{\mathrm{m}}}$ & $0.43 \pm 1.17$ & $1.1 \pm 0.4$ & - & $-0.06 \pm 0.02$ \\
\hline 2001-2008 (Atlantic) ${ }^{1}$ & $0.2 \pm 0.3$ & $0.2 \pm 1.0$ & - & $0.11 \pm 0.12$ \\
\hline
\end{tabular}

${ }^{\mathrm{a}}$ Bates et al. (2012), ${ }^{\mathrm{b}}$ Bates (2012), ${ }^{\mathrm{c}}$ Santana-Casiano et al. (2007), ${ }^{\mathrm{d}}$ Olafsson et al. (2009), ${ }^{\mathrm{e}}$ Wong et al. (2010), ${ }^{\mathrm{f}}$ Wakita et al. (2010), ${ }^{\mathrm{g}}$ Ishii et al. (2011), ${ }^{\mathrm{h}}$ Keeling et al. (2004), ${ }^{\mathrm{i}}$ Dore et al. (2009), ${ }^{\mathrm{j}}$ Feely et al. (2006), ${ }^{\mathrm{k}}$ Metzl (2009), ${ }^{\mathrm{l}}$ Lenton et al. (2013),

m Brix et al. (2013).

on annual means, we calculate trend and standard deviation over the period 1970-1999 (not shown). The ensemble mean trend pattern captures the main features of the reanalysis, with comparably strong trends in the equatorial and North Pacific, and the North Atlantic. However, the modeled trends are slightly lower and in general more homogeneous. The reanalysis shows a stronger gradient between regions with strong and very weak trends. Further, the reanalysis shows negative trends in the Pacific from 20 to $40^{\circ} \mathrm{N}$, which are not present in the ensemble mean. Globally, we find a pattern correlation $r$ between model ensemble and reanalysis of 0.44 $\left(90-20^{\circ} \mathrm{S}: 0.56 ; 20^{\circ} \mathrm{S}-20^{\circ} \mathrm{N}: 0.36\right.$; and $\left.20-90^{\circ} \mathrm{N}: 0.68\right)$. Concerning standard deviation, the picture is similar. Both ensemble mean and reanalysis capture main variability features such as the ENSO region or parts of the North Atlantic. However, again the ensemble mean is more homogeneous. The reanalysis indicates very low inter-annual variability in the high latitudes, especially the Southern Ocean, which is not the case for the model ensemble. We find a global pattern correlation $r$ of $0.88\left(90-20^{\circ} \mathrm{S}: 0.82 ; 20^{\circ} \mathrm{S}-20^{\circ} \mathrm{N}: 0.81\right.$; and $20-90^{\circ} \mathrm{N}: 0.89$ ).

To evaluate $N$, we can verify the presence of main characteristics of natural variability. One prominent feature is El Niño-Southern Oscillation (ENSO; Fiedler, 2002), located in the equatorial Pacific. This climate mode, the most impor- tant factor concerning natural variability in the climate system on global scales, is known to have substantial impact on the ocean carbon cycle in the affected area (e.g., Le Quéré et al., 2010; Wanninkhof et al., 2013) and the global air-sea $\mathrm{CO}_{2}$ flux in general (Siegenthaler, 1990; McKinley et al., 2004). We find clear indications of ENSO in the SD patterns of SST, DIC and $p \mathrm{CO}_{2}$, and a weak signal for $\mathrm{pH}$. Another area of high natural variability is the North Atlantic, which is influenced by modes like the North Atlantic Oscillation (NAO; Hurrell and Deser, 2009) or changes in the Atlantic Meridional Overturning Circulation (AMOC; Carton and Häkkinen, 2011), both known for affecting the ocean carbon cycle (e.g., Keller et al., 2012; Perez et al., 2013). A further region with high variability in the ocean carbon system is the Southern Ocean (see e.g., Bacastow, 1976; Marinov et al., 2006; Lovenduski et al., 2007; Le Quéré et al., 2007; Resplandy et al., 2013b), where we find a corresponding signal in the ensemble $\mathrm{SD} p \mathrm{CO}_{2}$ pattern.

In order to estimate the importance of trend and natural variability in shaping the spatial patterns of ToE, we compare patterns in $S$ and $N$ with the resulting ToE. For DIC, some areas of high ToE values, such as the Arctic Ocean and the eastern equatorial Pacific, are characterized by anticorrelated high variability levels and low trends. In the western equatorial Pacific, high ToE is due to high variability 


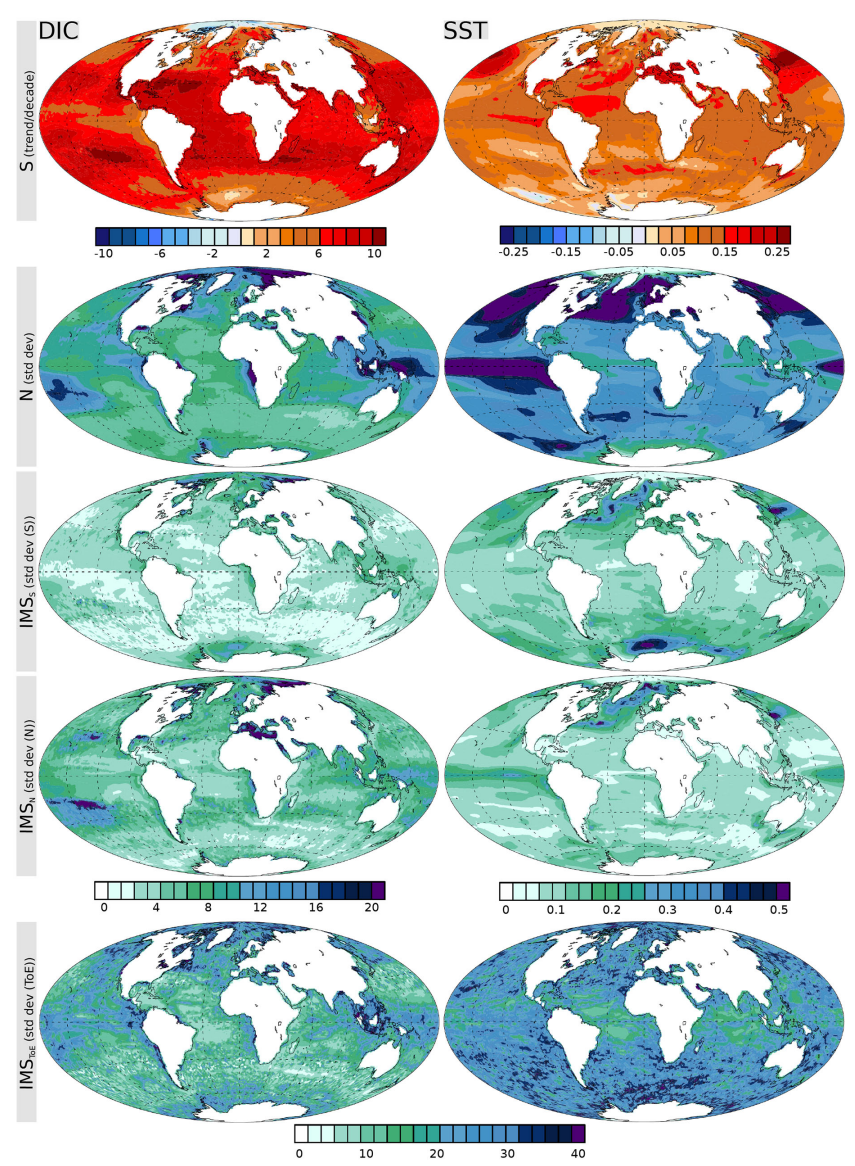

Figure 3a. Trend per decade $(S)$, standard deviation $(N)$ and, as measures for the inter-model spread (IMS), standard deviations of $S\left(\mathrm{IMS}_{S}\right), N\left(\mathrm{IMS}_{N}\right)$, and ToE (IMS $\mathrm{ToE}$; years) of dissolved inorganic carbon (DIC; $\mathrm{mmol} \mathrm{m}^{-3}$ ) and sea-surface temperature (SST; $\left.{ }^{\circ} \mathrm{C}\right)$.

alone, as $S$ shows medium levels. The opposite is the case in the North Pacific, where high ToE is caused by weak trend signals. The ToE pattern of $p \mathrm{CO}_{2}$ seems to be dominated by $N$, supported by anti-correlated low $S$ on local scales in the Southern Ocean. $N$ of $\mathrm{pH}$ is relatively homogeneous, with elevated variability levels in the Arctic Ocean, the Southern Ocean and, locally, the eastern equatorial Pacific. These areas imprint on the ToE pattern, yet $S$ seems to be more important. For the carbon cycle variables, $S$ and $N$ are found to be anti-correlated in some regions. The opposite is the case for SST, which shows both high trends and variability in the equatorial Pacific, the North Pacific, and parts of the North Atlantic. The associated high ToE values illustrate the dominance of $N$, which masks the strong trends in these areas. In the equatorial parts of the Atlantic, western Pacific and Indian Ocean, the absence of strong variability allows $S$ to govern the ToE field. In conclusion, we see that in areas with high natural variability, even strong trends both in the physi-

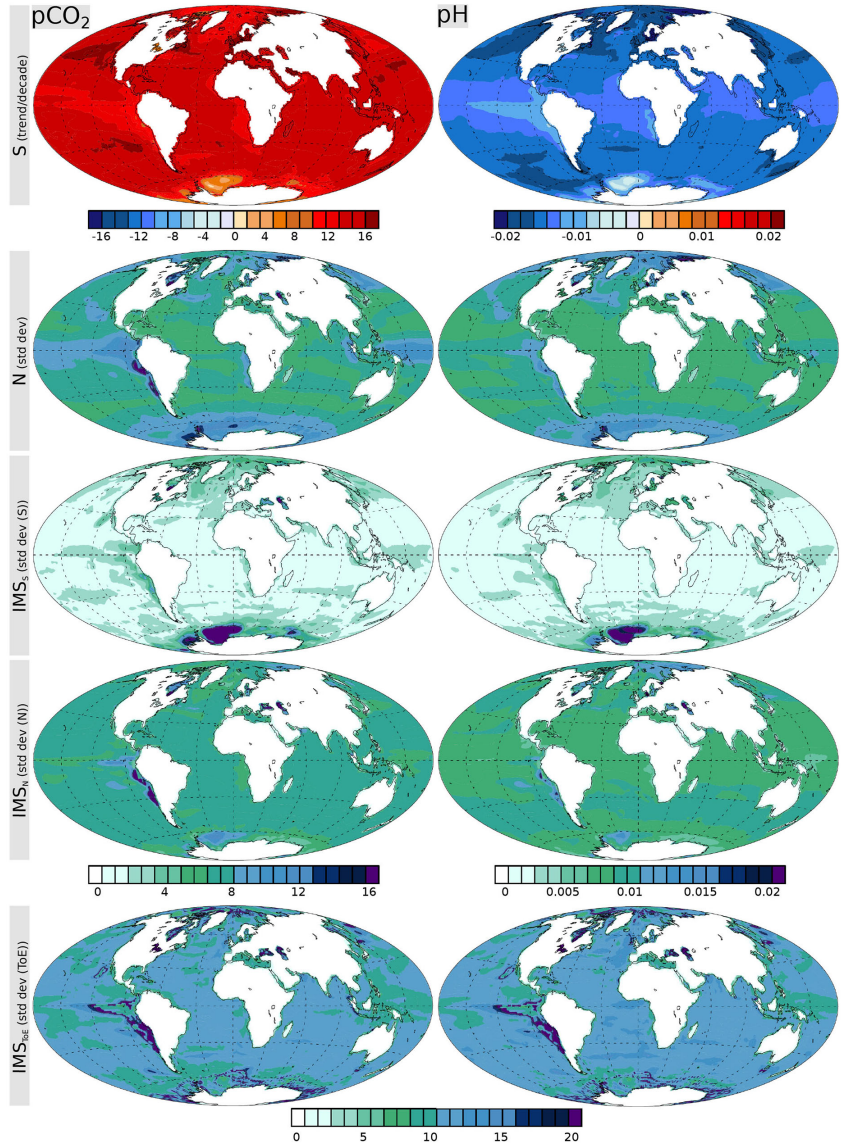

Figure 3b. Trend per decade $(S)$, standard deviation $(N)$ and, as measures for the inter-model spread (IMS), standard deviations of $S\left(\mathrm{IMS}_{S}\right), N\left(\mathrm{IMS}_{N}\right)$, and ToE $\left(\mathrm{IMS}_{\mathrm{ToE}}\right.$; years) of $p \mathrm{CO}_{2}(\mathrm{ppmv})$ and total $\mathrm{pH}$.

cal climate and carbon cycle system are masked over decadal timescales.

When working with a model ensemble, it is important to consider the inter-model spread (IMS). It illustrates where and when the models diverge and is thus a measure for uncertainty. Figure $3 \mathrm{a}$ and $3 \mathrm{~b}$ show the standard deviation across all 17 models of $S\left(\mathrm{IMS}_{S}\right), N\left(\mathrm{IMS}_{N}\right)$ and ToE $\left(\mathrm{IMS}_{\mathrm{ToE}}\right)$. The four IMS $S_{S}$ fields show related patterns, with high IMS in the Southern Ocean (all four variables), the Arctic Ocean (DIC and, weaker, $\mathrm{pH}$ and $p \mathrm{CO}_{2}$ ) and the North Atlantic (SST). The IMS ${ }_{N}$ field of SST mirrors the pattern of $\mathrm{IMS}_{S}$ in the North Atlantic, and the same is true for DIC in the subtropical Pacific and the eastern Arctic Ocean. $\mathrm{IMS}_{N}$ of $\mathrm{pH}$ indicates a large-scale zonal structure and shows, together with $p \mathrm{CO}_{2}$, high IMS in the upwelling region off Peru and Chile. The IMS $\mathrm{IoE}_{\mathrm{T}}$ field of DIC resembles the pattern for $N$, with high IMS in the Arctic and the equatorial Pacific Ocean. $\mathrm{IMS}_{\mathrm{ToE}}$ of $\mathrm{pH}$ and $p \mathrm{CO}_{2}$ are much alike, with large IMS localized in the Arctic and Southern Ocean and the eastern equatorial Pacific. IMS $\mathrm{IME}_{\mathrm{T}}$ of SST is very noisy, however 

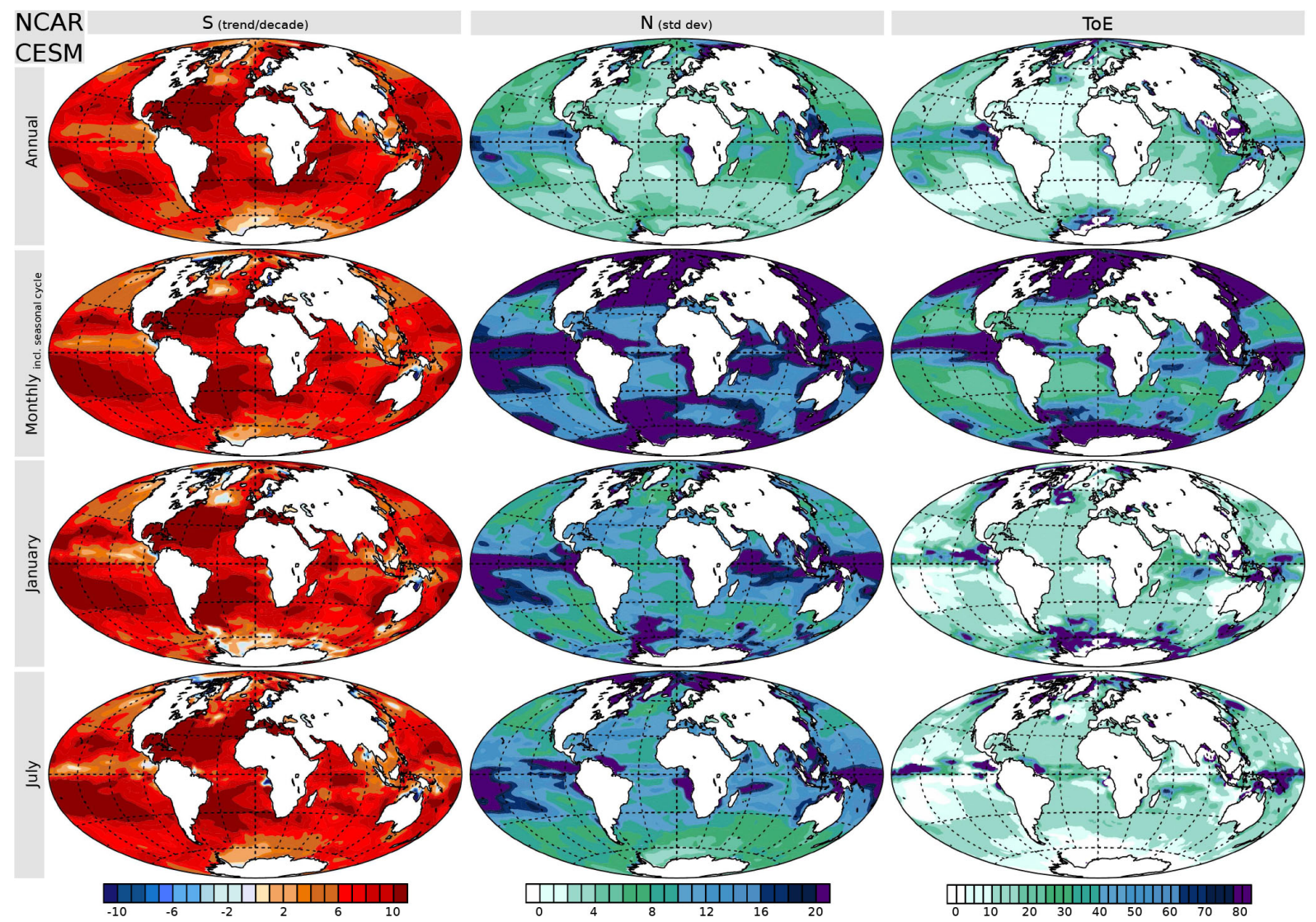

Figure 4. NCAR CESM1: Trend per decade $(S)$, standard deviation $(N)$ and ToE (years) of dissolved inorganic carbon $\left(D I C ; \mathrm{mmol} \mathrm{m}^{-3}\right.$ ) for the period 1975-2004. $S$ and $N$ are calculated on a basis of annual averages (\#30, row 1), monthly averages, including full seasonal cycle (\#360, row 2), January only (\#30, row 3), and July only (\#30, row 4).

with generally lower values around the equator. Possible reasons for the model spread in the Southern Ocean include the inadequate representation of bottom-water formation processes in many CMIP5 models (Heuzé et al., 2013) and a systematic wind bias inherent to many models, which impacts physical processes like Antarctic Circumpolar Current and Southern Ocean water mass formation and, consequently, the ocean carbon cycle (Swart and Fyfe, 2012). In areas with high natural variability, such as the equatorial Pacific or the North Atlantic, IMS might arise from differences in time and space of the representation of climate modes such as ENSO or NAO (e.g., Keller et al., 2012). Another possible factor is the model resolution, especially in areas dominated by local processes such as coastal upwelling.

\subsection{Impact of seasonality}

For 6 out of 17 models, we have monthly data available. These are NCAR CESM1 (the complete simulation, 18502005), NCAR CCSM3-BEC and NCAR CSM1.4-carbon (25 yr, 1985-2009), and BCCR BCM-C, IPSL-CM4 and COSMOS (30 yr, 1980-2009). A comparison based on annual averages of the complete $130 \mathrm{yr}$ and the monthly data
(NCAR CESM1: 1975-2004) provides very similar results. Accordingly, we assume that time periods of 25 and $30 \mathrm{yr}$ are sufficient to capture main variability features and that results based on this data are robust. As mentioned in Sect. 2, we find that the trend patterns of all four variables are indeed comparable for the different timescales. The fields of standard deviation, however, differ. The regions mainly affected by intra-annual variability are the high latitudes. For DIC, as an example, the monthly averages over the time series display a clear seasonal cycle for four out of six models (NCAR CESM1, CCSM3-BEC, NCAR CSM1.4-carbon and COSMOS), while others show comparably homogeneous patterns throughout the year (BCCR BCM-C, IPSL-CM4). For both $\mathrm{pH}$ and $p \mathrm{CO}_{2}$ we find seasonal signals for the models NCAR CESM1, COSMOS and IPSL-CM4 and, more limited to the Southern Ocean, BCCR BCM-C. SST shows a strong seasonal cycle in all six models. To illustrate (i) the differences between the models and (ii) to give an estimate of the importance of the seasonal cycle, we show results for DIC of two models. These are NCAR CESM1, a model with distinct seasonal cycle, and IPSL-CM4, a model with comparably small intra-annual variability. 

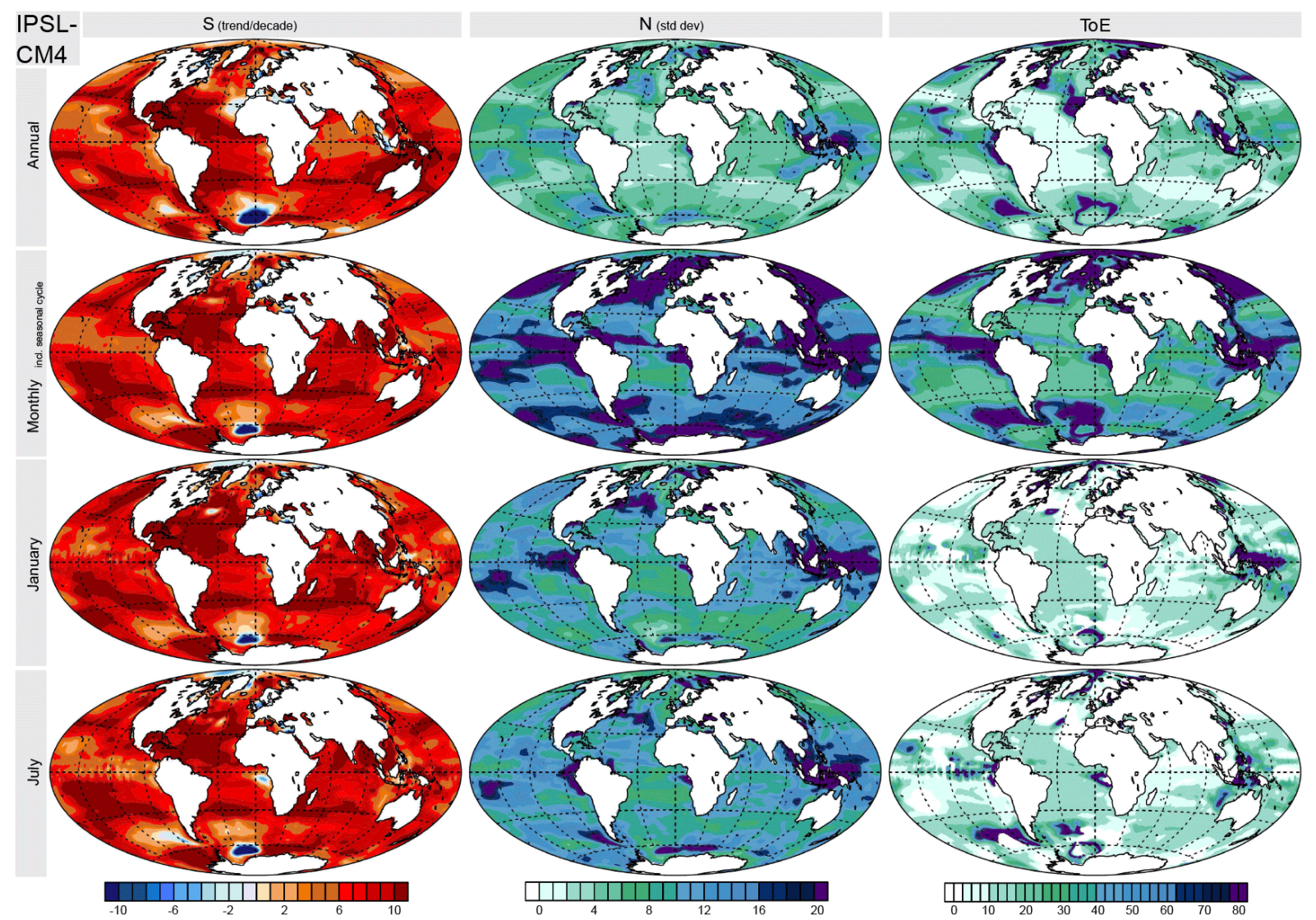

Figure 5. IPSL-CM4: Trend per decade $(S)$, standard deviation $(N)$ and ToE (years) of dissolved inorganic carbon (DIC; $\mathrm{mmol} \mathrm{m}^{-3}$ ) for the period 1980-2009. $S$ and $N$ are calculated on a basis of annual averages (\#30, row 1), monthly averages, including full seasonal cycle (\#360, row 2), January only (\#30, row 3), and July only (\#30, row 4).

Figures 4 and 5 show $S, N$ and ToE of surface DIC for the models NCAR CESM1 and IPSL-CM4, respectively. The fields are calculated using the same $30 \mathrm{yr}$ of monthly data (NCAR: 1975-2004, IPSL: 1980-2009), albeit with different temporal resolutions: annual averages (\#30, row 1), monthly averages, including full seasonal cycle (\#360, row 2), January only (\#30, row 3 ) and July only (\#30, row 4). For case two (monthly averages), an alternative approach would be to define $N$ as the full range of the seasonal cycle. In doing so, it is possible to make a clear distinction between inter- and intra-annual variability. However, we focus on the combination of both since it is closer to what we find in reality. For both models, $S$ is comparable concerning magnitude and spatial patterns in all four cases. One exception is the area around (IPSL) or east of Australia (CESM), which shows strong trends in the annual averages. A comparison of the cases "Annual" and "Monthly" illustrates the expected loss of variability due to temporal averaging, especially in this case where the seasonal cycle is still present in the monthly data. Consistent with the ensemble mean, the two "Annual" $N$ fields show variability hot-spots in the equatorial Pacific and, locally, the Arctic Ocean. When the seasonal cycle comes into play, general variability is increased substantially by a factor up to 4 and more. On a spatial scale, "Monthly" captures the main features of "Annual". Additional areas with high variability, that is, regions with a pronounced seasonal cycle, are the North Atlantic, the western North Pacific and the Southern Ocean, especially the Drake Passage and Scotia Sea. Further, we look at January and July as representatives of northern summer and winter. When focusing on single months, the seasonal cycle has no relevance for the magnitude of $N$. Consequently, the result are $N$ fields slightly higher than in the "Annual" case, reason being the absence of averaging-based losses in the January/July cases. One important difference between the models remains. The January and July fields of IPSL are much alike. In contrast to this (and representative for the majority of the models), for NCAR, variability in the high latitudes on both hemispheres is much higher in the respective summer season. For both models and in agreement with the ensemble mean, ToE fields are tightly linked to $N$. The differences between seasons in the NCAR model are caused by the mentioned seasonal signal of intra-annual variability. To simplify the comparison, Fig. 6 shows ToE "Annual" (row 1) and, for "Monthly" (row 


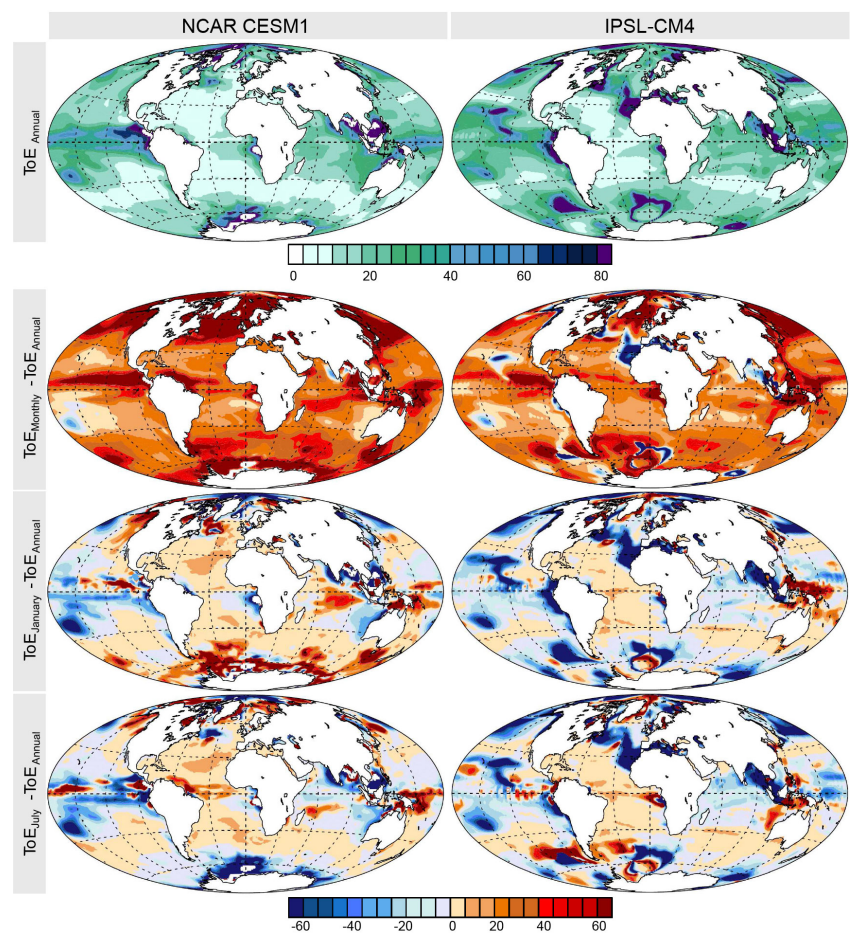

Figure 6. NCAR CESM1 and IPSL-CM4: ToE "Annual" (row 1; same as in Figs. 4 and 5) and, for the cases "Monthly" (row 2), "January" (row 3), and "July" (row 4), the offset relative to this case (e.g., row 2: ToE $E_{\text {Monthly }}-$ ToE $\left._{\text {Annual }}\right)$.

2), "January" (row 3) and "July" (row 4), the offset relative to this case (e.g., row 2: ToE Monthly $-\mathrm{ToE}_{\text {Annual }}$ ). ToE "Monthly" of both models shows the expected substantially later ToE as the "Annual" case. "January" and "July" show comparable $( \pm 10 \mathrm{yr}) \mathrm{ToE}$ to the "Annual" case in large parts of the global oceans, especially in the low and middle latitudes. However, the NCAR model shows large deviations (up to $\pm 60 \mathrm{yr}$ and more) in the high latitudes, the equatorial Pacific, the Indian Ocean and, more localized, in other areas. This has important implications for observations. The "January/July" patterns are similar in parts of the global oceans. This indicates that, at these locations, statements based on irregularly sampled data are valid representatives for the whole year. In large areas, however, intra-annual variability might interfere such a generalization. An illustrative example is the slowdown of the AMOC, which was suggested by Bryden et al. (2005) based on five cross sections in the North Atlantic. These snap-shot measurements were distributed over the seasons in such a way that they embraced the full range of the seasonal cycle, and the observed slow-down was later attributed mainly to "aliasing due to seasonal anomalies" (Kanzow et al., 2010).

\section{Conclusions}

Here, we investigate the time of emergence (ToE) of trends in the surface ocean carbon cycle utilizing an ensemble of 17 state-of-the-art ESMs. The ToE is the time required until a sustained trend exceeds a variability threshold (here two standard deviations). Thus, ToE depends on reliable estimates of both trend and variability. For example, an underestimation of the variability in the model compared to the real ocean would bias ToE towards low values. Yet, the study shows that the ensemble mean trend and standard deviation patterns are in reasonable agreement with observations and reanalysis data sets, which supports the robustness of the presented results.

ToE of $\mathrm{pH}$ and $p \mathrm{CO}_{2}$ has rather low values (around $10 \mathrm{yr}$ ) in many regions of the surface ocean. It is, however, generally difficult if not impossible to reliably determine variability and long-term trends in the surface ocean from data that extend over such a short period only. Trends in surface ocean variables can vary significantly between different $10 \mathrm{yr}$ periods and even reverse sign (see Fig. 1 and Table 1, ALOHA data for an illustration). As a consequence, model data, or measurements, over a longer period are needed to reliably determine anthropogenic trends (Fay and McKinley, 2013) and the ToE. Here, trends and variability are estimated from $30 \mathrm{yr}$ (1970 to 1999) and $130 \mathrm{yr}$ of model data, respectively. The choice of a $30 \mathrm{yr}$ period minimizes the influence of climate modes such as NAO, ENSO or AMOC on trends as demonstrated by Fay and McKinley (2013) for surface ocean $p \mathrm{CO}_{2}$ measurements, while at the same time the 1970 to 2000 period still provides an approximate measure of the current and near-future anthropogenic trend in the surface ocean. The ToE is indicative for the time required for the anthropogenic trend to leave the variability band, but it should not be confused with the period required to detect this trend in observational or model data.

We find that trend signals in ocean biogeochemical variables emerge on much shorter timescales than the physical climate variable SST. ToE fields of $p \mathrm{CO}_{2}$ and $\mathrm{pH}$ are spatially very similar to DIC, yet emerge much faster - after $\approx 12 \mathrm{yr}$ for the majority of the global ocean area, compared to $\approx 10-30 \mathrm{yr}$ for DIC. Assuming that natural variability is constant over time, we suggest that possible stronger future trends would emerge accordingly faster. We find that, in general, the standard deviation is of higher importance in determining ToE than the strength of the linear trend. In areas with high natural variability, even strong trends both in the physical climate and carbon cycle system are masked by variability over decadal timescales. This explains inconsistencies in trends based on time series of insufficient length to overcome natural variability, and illustrates the necessity for long-term observations.

Considering past changes since the beginning of the industrialization, the fast emergence of trend signals implies that anthropogenic trends in the surface ocean carbon cycle are 
already detectable in large parts of the global oceans. This finding is even more relevant as the highest rates of ocean acidification are measured (Bates, 2012; Dore et al., 2009) and modeled (Resplandy et al., 2013a) in subsurface waters.

A further finding of the study is that, in contrast to the trend, the standard deviation is affected by the seasonal cycle. This has important implications for the use of sparse observations. In some parts of the global oceans, there are hints that statements based on irregularly sampled seasonal data might be representative for the whole year. In large areas, however, intra-annual variability might interfere such a generalization.

The study clearly illustrates the need for more long-term measurements with sufficient seasonal data coverage. DIC is a very important variable and crucial for our understanding of processes. For the sole detection of trends, however, $p \mathrm{CO}_{2}$ and $\mathrm{pH}$ seem to be a better choice. Further, observations are not only necessary for the correct detection of trends and natural variability. Independent data sets are also key for the robust forcing and evaluation of climate models which are, since observations are still scarce, the measure of choice for many research questions.

Acknowledgements. We thank Juliette Mignot and Jim Orr for discussion and comments. The research leading to these results was supported through EU FP7 project CARBOCHANGE "Changes in carbon uptake and emissions by oceans in a changing climate", which received funding from the European Community's Seventh Framework Programme under grant agreement no. 264879. Additional support was received from the Swiss National Science Foundation. We thank IPSL and ETHZ for providing the model data of OCMIP5 and CMIP5. Simulations with NCAR CESM1 were carried out at the Swiss National Supercomputing Centre in Lugano, Switzerland.

Edited by: L. Cotrim da Cunha

\section{References}

Assmann, K. M., Bentsen, M., Segschneider, J., and Heinze, C.: An isopycnic ocean carbon cycle model, Geosci. Model Dev., 3, 143-167, doi:10.5194/gmd-3-143-2010, 2010.

Aumont, O., Maier-Reimer, E., Blain, S., and Monfray, P.: An ecosystem model of the global ocean including $\mathrm{Fe}$, Si, P colimitations, Global Biogeochem. Cy., 17, 1060, doi:10.1029/2001GB001745, 2003.

Bacastow, R. B.: Modulation of atmospheric carbon dioxide by the Southern Oscillation, Nature, 261, 116-118, 1976.

Bates, N. R.: Multi-decadal uptake of carbon dioxide into subtropical mode water of the North Atlantic Ocean, Biogeosciences, 9, 2649-2659, doi:10.5194/bg-9-2649-2012, 2012.

Bates, N. R., Best, M. H. P., Neely, K., Garley, R., Dickson, A. G., and Johnson, R. J.: Detecting anthropogenic carbon dioxide uptake and ocean acidification in the North Atlantic Ocean, Biogeosciences, 9, 2509-2522, doi:10.5194/bg-9-2509-2012, 2012.

Bopp, L., Resplandy, L., Orr, J. C., Doney, S. C., Dunne, J. P., Gehlen, M., Halloran, P., Heinze, C., Ilyina, T., Séférian, R.,
Tjiputra, J., and Vichi, M.: Multiple stressors of ocean ecosystems in the 21st century: projections with CMIP5 models, Biogeosciences, 10, 6225-6245, doi:10.5194/bg-10-6225-2013, 2013.

Brix, H., Currie, K. I., and Mikaloff Fletcher, S. E.: Seasonal variability of the carbon cycle in subantarctic surface water in the South West Pacific, Global Biogeochem. Cy., 27, 200-211, 2013.

Bryden, H. L., Longworth, H. R., and Cunningham, S. A.: Slowing of the Atlantic meridional overturning circulation at $25^{\circ} \mathrm{N}$, Nature, 438, 655-657, 2005.

Carton, J. A. and Häkkinen, S.: Introduction to: Atlantic Meridional Overturning Circulation (AMOC), Deep-Sea Res. Pt. II, 58, 1741-1743, 2011.

Christian, J. R., Arora, V. K., Boer, G. J., Curry, C. L., Zahariev, K., Denman, K. L., Flato, G. M., Lee, W. G., Merryfield, W. J., Roulet, N. T., and Scinocca, J. F.: The global carbon cycle in the Canadian Earth system model (CanESM1): preindustrial control simulation, J. Geophys. Res.-Biogeo., 115, G03014, doi:10.1029/2008JG000920, 2010.

Cocco, V., Joos, F., Steinacher, M., Frölicher, T. L., Bopp, L., Dunne, J., Gehlen, M., Heinze, C., Orr, J., Oschlies, A., Schneider, B., Segschneider, J., and Tjiputra, J.: Oxygen and indicators of stress for marine life in multi-model global warming projections, Biogeosciences, 10, 1849-1868, doi:10.5194/bg-10-18492013, 2013.

Collins, W. D., Bitz, C. M., Blackmon, M. L., Bonan, G. B., Bretherton, C. S., Carton, J. A., Chang, P., Doney, S. C., Hack, J. J., Henderson, T. B., Kiehl, J. T., Large, W. G., McKenna, D. S., Santer, B. D., and Smith, R. D.: The Community Climate System Model version 3 (CCSM3), J. Climate, 19, 2122-2143, 2006.

Diffenbaugh, N. and Giorgi, F.: Climate change hotspots in the CMIP5 global climate model ensemble, Climatic Change, 114, 813-822, 2012.

Diffenbaugh, N. and Scherer, M.: Observational and model evidence of global emergence of permanent, unprecedented heat in the 20th and 21st centuries, Climatic Change, 107, 615-624, 2011.

Dolman, A. J., van der Werf, G. R., van der Molen, M. K., Ganssen, G., Erisman, J. W., and Strengers, B.: A carbon cycle science update since IPCC AR-4, Ambio, 39, 402-412, 2010.

Doney, S. C., Lindsay, K., Fung, I., and John, J.: Natural variability in a stable, 1000-yr global coupled climate-carbon cycle simulation, J. Climate, 19, 3033-3054, 2006.

Dore, J. E., Lukas, R., Sadler, D. W., Church, M. J., and Karl, D. M.: Physical and biogeochemical modulation of ocean acidification in the central North Pacific, P. Natl. Acad. Sci. USA, 106, 1223512240, 2009.

Dunne, J. P., John, J. G., Shevliakova, E., Stouffer, R. J., Krasting, J. P., Malyshev, S. L., Milly, P. C. D., Sentman, L. T., Adcroft, A. J., Cooke, W., Dunne, K. A., Griffies, S. M., Hallberg, R. W., Harrison, M. J., Levy, H., Wittenberg, A. T., Phillips, P. J., and Zadeh, N.: GFDL's ESM2 Global coupled climate-carbon Earth System Models. Part II: Carbon system formulation and baseline simulation characteristics, J. Climate, 26, 2247-2267, 2012.

Dutkiewicz, S., Scott, J. R., and Follows, M. J.: Winners and losers: ecological and biogeochemical changes in a warming ocean, Global Biogeochem. Cy., 27, 463-477, 2013. 
Enting, I. G.: On the use of smoothing splines to filter $\mathrm{CO}_{2}$ data, J. Geophys. Res.-Atmos., 92, 10977-10984, 1987.

Fay, A. R. and McKinley, G. A.: Global trends in surface ocean $p \mathrm{CO}_{2}$ from in situ data, Global Biogeochem. Cy., 27, 541-557, 2013.

Feely, R. A., Takahashi, T., Wanninkhof, R., McPhaden, M. J., Cosca, C. E., Sutherland, S. C., and Carr, M.-E.: Decadal variability of the air-sea $\mathrm{CO}_{2}$ fluxes in the equatorial Pacific Ocean, J. Geophys. Res.-Oceans, 111, C08S90, doi:10.1029/2005JC003129, 2006.

Fiedler, P.: Environmental change in the eastern tropical Pacific Ocean: review of ENSO and decadal variability, Mar. Ecol.-Prog. Ser., 244, 265-283, 2002.

Friedrich, T., Timmermann, A., Abe-Ouchi, A., Bates, N. R., Chikamoto, M. O., Church, M. J., Dore, J. E., Gledhill, D. K., Gonzalez-Davila, M., Heinemann, M., Ilyina, T., Jungclaus, J. H., McLeod, E., Mouchet, A., and SantanaCasiano, J. M.: Detecting regional anthropogenic trends in ocean acidification against natural variability, Nat. Clim. Change, 2, 167-171, 2012

Frölicher, T. L., Joos, F., Plattner, G. K., Steinacher, M., and Doney, S. C.: Natural variability and anthropogenic trends in oceanic oxygen in a coupled carbon cycle-climate model ensemble, Global Biogeochem. Cy., 23, GB1003, doi:10.1029/2008GB003316, 2009.

Giorgi, F. and Bi, X.: Time of emergence (TOE) of GHG-forced precipitation change hot-spots, Geophys. Res. Lett., 36, L06709, doi:10.1029/2009GL037593, 2009.

Hauri, C., Gruber, N., Vogt, M., Doney, S. C., Feely, R. A., Lachkar, Z., Leinweber, A., McDonnell, A. M. P., Munnich, M., and Plattner, G.-K.: Spatiotemporal variability and long-term trends of ocean acidification in the California Current System, Biogeosciences, 10, 193-216, doi:10.5194/bg-10-1932013, 2013.

Hawkins, E. and Sutton, R.: Time of emergence of climate signals, Geophys. Res. Lett., 39, L01702, doi:10.1029/2011GL050087, 2012.

Hegerl, G. C., Zwiers, F. W., Braconnot, P., Gillett, N., Luo, Y., Orsini, J. M., Nicholls, N., Penner, J., and Stott, P.: Understanding and attributing climate change, in: Climate Change 2007: The Physical Science Basis, Contribution of Working Group I to the Fourth Assessment Report of the Intergovernmental Panel on Climate Change, edited by: Solomon, S., Qin, D., Manning, M., Chen, Z., Marquis, M., Averyt, K. B., Tignor, M., and Miller, H. L., Cambridge University Press, Cambridge, UK and New York, NY, USA, 2007.

Heuzé, C., Heywood, K. J., Stevens, D. P., and Ridley, J. K.: Southern Ocean bottom water characteristics in CMIP5 models, Geophys. Res. Lett., 40, 1409-1414, 2013.

Hurrell, J. W. and Deser, C.: North Atlantic climate variability: the role of the North Atlantic Oscillation, J. Mar. Syst., 78, 28-41, 2009.

Ilyina, T. and Zeebe, R. E.: Detection and projection of carbonate dissolution in the water column and deep-sea sediments due to ocean acidification, Geophys. Res. Lett., 39, L06606, doi:10.1029/2012GL051272, 2012.

Ilyina, T., Zeebe, R. E., Maier-Reimer, E., and Heinze, C.: Early detection of ocean acidification effects on ma- rine calcification, Global Biogeochem. Cy., 23, GB1008, doi:10.1029/2008GB003278, 2009.

Ilyina, T., Six, K. D., Segschneider, J., Maier-Reimer, E., Li, H., and Núñez-Riboni, I.: Global ocean biogeochemistry model HAMOCC: model architecture and performance as component of the MPI-Earth system model in different CMIP5 experimental realizations, J. Adv. Model. Earth Syst., 5, 287-315, doi:10.1029/2012MS000178, 2013.

Ishii, M., Kosugi, N., Sasano, D., Saito, S., Midorikawa, T., and Inoue, H. Y.: Ocean acidification off the south coast of Japan: a result from time series observations of $\mathrm{CO}_{2}$ parameters from 1994 to 2008, J. Geophys. Res.-Oceans, 116, C06022, doi:10.1029/2010JC006831, 2011.

Joos, F., Plattner, G., Stocker, T., Marchal, O., and Schmittner, A.: Global warming and marine carbon cycle feedbacks on future atmospheric $\mathrm{CO}_{2}$, Science, 284, 464-467, 1999.

Jungclaus, J. H., Keenlyside, N., Botzet, M., Haak, H., Luo, J. J., Latif, M., Marotzke, J., Mikolajewicz, U., and Roeckner, E.: Ocean circulation and tropical variability in the coupled model ECHAM5/MPI-OM, J. Climate, 19, 3952-3972, 2006.

Kanzow, T., Cunningham, S. A., Johns, W. E., Hirschi, J. J.-M., Marotzke, J., Baringer, M. O., Meinen, C. S., Chidichimo, M. P., Atkinson, C., Beal, L. M., Bryden, H. L., and Collins, J.: Seasonal variability of the Atlantic Meridional Overturning Circulation at $26.5^{\circ} \mathrm{N}$, J. Climate, 23, 5678-5698, 2010.

Karoly, D. J. and Wu, Q.: Detection of regional surface temperature trends, J. Climate, 18, 4337-4343, 2005.

Keeling, C. D., Brix, H., and Gruber, N.: Seasonal and longterm dynamics of the upper ocean carbon cycle at Station ALOHA near Hawaii, Global Biogeochem. Cy., 18, GB4006, doi:10.1029/2004GB002227, 2004.

Keeling, R. F., Körtzinger, A., and Gruber, N.: Ocean deoxygenation in a warming world, Annu. Rev. Mar. Sci., 2, 199-229, 2010.

Keller, K., Joos, F., Raible, C., Cocco, V., Frölicher, T., Dunne, J., Gehlen, M., Bopp, L., Orr, J., Tjiputra, J., Heinze, C., Segschneider, J., Roy, T., and Metzl, N.: Variability of the ocean carbon cycle in response to the North Atlantic Oscillation, Tellus B, 64, 18738, doi:10.3402/tellusb.v64i0.18738, 2012.

Latif, M., Kleeman, R., and Eckert, C.: Greenhouse warming, decadal variability, or El Niño? An attempt to understand the anomalous 1990s, J. Climate, 10, 2221-2239, 1997.

Le Quéré, C., Roedenbeck, C., Buitenhuis, E. T., Conway, T. J., Langenfelds, R., Gomez, A., Labuschagne, C., Ramonet, M., Nakazawa, T., Metzl, N., Gillett, N., and Heimann, M.: Saturation of the Southern Ocean $\mathrm{CO}_{2}$ sink due to recent climate change, Science, 316, 1735-1738, 2007.

Le Quéré, C., Takahashi, T., Buitenhuis, E. T., Roedenbeck, C., and Sutherland, S. C.: Impact of climate change and variability on the global oceanic sink of $\mathrm{CO}_{2}$, Global Biogeochem. Cy., 24, GB4007, doi:10.1029/2009GB003599, 2010.

Lenton, A., Tilbrook, B., Law, R. M., Bakker, D., Doney, S. C., Gruber, N., Ishii, M., Hoppema, M., Lovenduski, N. S., Matear, R. J., McNeil, B. I., Metzl, N., Mikaloff Fletcher, S. E., Monteiro, P. M. S., Rödenbeck, C., Sweeney, C., and Takahashi, T.: Sea-air $\mathrm{CO}_{2}$ fluxes in the Southern Ocean for the period 1990 2009, Biogeosciences, 10, 4037-4054, doi:10.5194/bg-10-40372013, 2013.

Levermann, A., Clark, P. U., Marzeion, B., Milne, G. A., Pollard, D., Radic, V., and Robinson, A.: The multimillennial sea- 
level commitment of global warming, P. Natl. Acad. Sci. USA, 110, 13745-13750, 2013.

Lovenduski, N. S., Gruber, N., Doney, S. C., and Lima, I. D.: Enhanced $\mathrm{CO}_{2}$ outgassing in the Southern Ocean from a positive phase of the Southern Annular Mode, Global Biogeochem. Cy., 21, GB2026, doi:10.1029/2006GB002900, 2007.

Mahlstein, I., Knutti, R., Solomon, S., and Portmann, R. W.: Early onset of significant local warming in low latitude countries, Environ. Res. Lett., 6, 034009, doi:10.1088/1748-9326/6/3/034009, 2011.

Mahlstein, I., Hegerl, G., and Solomon, S.: Emerging local warming signals in observational data, Geophys. Res. Lett., 39, L21711, doi:10.1029/2012GL053952, 2012.

Mahlstein, I., Daniel, J. S., and Solomon, S.: Pace of shifts in climate regions increases with global temperature, Nat. Clim. Change, 3, 739-743, 2013.

Marinov, I., Gnanadesikan, A., Toggweiler, J., and Sarmiento, J.: The Southern Ocean biogeochemical divide, Nature, 441, 964 967, 2006

McKinley, G., Rodenbeck, C., Gloor, M., Houweling, S., and Heimann, M.: Pacific dominance to global air-sea $\mathrm{CO}_{2}$ flux variability: a novel atmospheric inversion agrees with ocean models, Geophys. Res. Lett., 31, L22308, doi:10.1029/2004GL021069, 2004.

McKinley, G. A., Fay, A. R., Takahashi, T., and Metzl, N.: Convergence of atmospheric and North Atlantic carbon dioxide trends on multidecadal timescales, Nat. Geosci., 4, 606-610, 2011.

Metzl, N.: Decadal increase of oceanic carbon dioxide in Southern Indian Ocean surface waters (1991-2007), Deep-Sea Res. Pt. II, 56, 607-619, 2009.

Moore, J. K., Lindsay, K., Doney, S. C., Long, M. C., and Misumi, K.: Marine Ecosystem Dynamics and Biogeochemical Cycling in the Community Earth System Model [CESM1(BGC)]: Comparison of the 1990s with the 2090s under the RCP4.5 and RCP8.5 Scenarios, J. Climate, 26, 9291-9312, 2013.

Mora, C., Frazier, A. G., Longman, R. J., Dacks, R. S., Walton, M. M., Tong, E. J., Sanchez, J. J., Kaiser, L. R., Stender, Y. O., Anderson, J. M., Ambrosino, C. M., FernandezSilva, I., Giuseffi, L. M., and Giambelluca, T. W.: The projected timing of climate departure from recent variability, Nature, 502, 183-187, 2013.

Olafsson, J., Olafsdottir, S. R., Benoit-Cattin, A., Danielsen, M., Arnarson, T. S., and Takahashi, T.: Rate of Iceland Sea acidification from time series measurements, Biogeosciences, 6, 26612668, doi:10.5194/bg-6-2661-2009, 2009.

Palmer, J. and Totterdell, I.: Production and export in a global ocean ecosystem model, Deep-Sea Res. Pt. I, 48, 1169-1198, 2001.

Perez, F. F., Mercier, H., Vazquez-Rodriguez, M., Lherminier, P., Velo, A., Pardo, P. C., Roson, G., and Rios, A. F.: Atlantic Ocean $\mathrm{CO}_{2}$ uptake reduced by weakening of the meridional overturning circulation, Nat. Geosci., 6, 146-152, 2013.

Raible, C., Stocker, T., Yoshimori, M., Renold, M., Beyerle, U., Casty, C., and Luterbacher, J.: Northern hemispheric trends of pressure indices and atmospheric circulation patterns in observations, reconstructions, and coupled GCM simulations, J. Climate, 18, 3968-3982, 2005.

Rayner, N., Parker, D., Horton, E., Folland, C., Alexander, L., Rowell, D., Kent, E., and Kaplan, A.: Global analyses of sea surface temperature, sea ice, and night marine air temperature since the late nineteenth century, J. Geophys. Res.-Atmos, 108, 4407, doi:10.1029/2002JD002670, 2003.

Resplandy, L., Bopp, L., Orr, J. C., and Dunne, J. P.: Role of mode and intermediate waters in future ocean acidification: analysis of CMIP5 models, Geophys. Res. Lett., 40, 3091-3095, $2013 \mathrm{a}$.

Resplandy, L., Boutin, J., and Merlivat, L.: Observed small spatial scale and seasonal variability of the $\mathrm{CO}_{2}$-system in the Southern Ocean, Biogeosciences Discuss., 10, 13855-13895, doi:10.5194/bgd-10-13855-2013, 2013 b.

Revelle, R. and Suess, H.: Carbon Dioxide Exchange Between Atmosphere and Ocean and the Question of an Increase of Atmospheric $\mathrm{CO}_{2}$ during the Past Decades, Tellus, 9, 18-27, 1957.

Santana-Casiano, J. M., Gonzalez-Davila, M., Rueda, M.-J., Llinas, O., and Gonzalez-Davila, E.-F.: The interannual variability of oceanic $\mathrm{CO}_{2}$ parameters in the northeast Atlantic subtropical gyre at the ESTOC site, Global Biogeochem. Cy., 21, GB1015, doi:10.1029/2006GB002788, 2007.

Santer, B. D., Mears, C., Doutriaux, C., Caldwell, P., Gleckler, P. J., Wigley, T. M. L., Solomon, S., Gillett, N. P., Ivanova, D., Karl, T. R., Lanzante, J. R., Meehl, G. A., Stott, P. A., Taylor, K. E., Thorne, P. W., Wehner, M. F., and Wentz, F. J.: Separating signal and noise in atmospheric temperature changes: the importance of timescale, J. Geophys. Res.-Atmos, 116, D22105, doi:10.1029/2011JD016263, 2011.

Séférian, R., Bopp, L., Swingedouw, D., and Servonnat, J.: Dynamical and biogeochemical control on the decadal variability of ocean carbon fluxes, Earth Syst. Dynam., 4, 109-127, doi:10.5194/esd-4-109-2013, 2013.

Siegenthaler, U.: Biogeochemical cycles - El Nino and atmospheric $\mathrm{CO}_{2}$, Nature, 345, 295-296, 1990.

Steinacher, M., Joos, F., Frölicher, T. L., Plattner, G.-K., and Doney, S. C.: Imminent ocean acidification in the Arctic projected with the NCAR global coupled carbon cycle-climate model, Biogeosciences, 6, 515-533, doi:10.5194/bg-6-5152009, 2009.

Swart, N. C. and Fyfe, J. C.: Ocean carbon uptake and storage influenced by wind bias in global climate models, Nat. Clim. Change, 2, 47-52, 2012.

Taylor, K. E., Stouffer, R. J., and Meehl, G. A.: An overview of CMIP5 and the experiment design, B. Am. Meteorol. Soc., 93, 485-498, 2011.

Tjiputra, J. F., Roelandt, C., Bentsen, M., Lawrence, D. M., Lorentzen, T., Schwinger, J., Seland, Ø., and Heinze, C.: Evaluation of the carbon cycle components in the Norwegian Earth System Model (NorESM), Geosci. Model Dev., 6, 301-325, doi:10.5194/gmd-6-301-2013, 2013.

Wakita, M., Watanabe, S., Murata, A., Tsurushima, N., and Honda, M.: Decadal change of dissolved inorganic carbon in the subarctic western North Pacific Ocean, Tellus B, 62, 608-620, 2010.

Wanninkhof, R., Park, G.-H., Takahashi, T., Sweeney, C., Feely, R., Nojiri, Y., Gruber, N., Doney, S. C., McKinley, G. A., Lenton, A., Le Quéré, C., Heinze, C., Schwinger, J., Graven, H., and Khatiwala, S.: Global ocean carbon uptake: magnitude, variability and trends, Biogeosciences, 10, 1983-2000, doi:10.5194/bg-101983-2013, 2013.

Watanabe, S., Hajima, T., Sudo, K., Nagashima, T., Takemura, T., Okajima, H., Nozawa, T., Kawase, H., Abe, M., Yokohata, T., Ise, T., Sato, H., Kato, E., Takata, K., Emori, S., and 
Kawamiya, M.: MIROC-ESM 2010: model description and basic results of CMIP5-20c3m experiments, Geosci. Model Dev., 4, 845-872, doi:10.5194/gmd-4-845-2011, 2011.
Wong, C., Christian, J. R., Wong, S.-K. E., Page, J., Xie, L., and Johannessen, S.: Carbon dioxide in surface seawater of the eastern North Pacific Ocean (Line P), 1973-2005, Deep-Sea Res. Pt. I, 57, 687-695, 2010 